\title{
Perception of Indian Youth towards Yagya
}

\author{
Pankaj Singh Chandel ${ }^{1}$, Chirayu Vats ${ }^{2}$, Umakant Indolia ${ }^{3}$ \\ ${ }^{1}$ Research Scholar, Department of Tourism Management, Dev Sanskriti University, Haridwar, India \\ ${ }^{2}$ International Relations Office, Dev Sanskriti University, Haridwar, India \\ ${ }^{3}$ Assistant Professor, Department of Tourism Management, Dev Sanskriti University, Haridwar, India \\ *Corresponding. Email: pankaj.chandel@dsvv.ac.in \\ https://doi.org/10.36018/ijyr.v4i1.65
}

\begin{abstract}
Understanding Indian cultural and ritual perspective of India has been important aspect of the sociologists and culturists. Perspective on Indian culture can be availed through understanding of Yagya as it is the basis of Indian culture. Survey by Nielsen Corporation has shown the proud feeling of Indians towards their culture while Wiber J Scott indicated that Indian students studying in America had gone to a level of 'difficult situation' towards understanding their culture and spirituality. Hence, the present study aimed to find understanding-level of youth (18-40 years) towards contemporary scenario of Yagya. The survey-questionnaire (self-prepared, Google form) was circulated through digital platforms. 566 participants had responded from the different disciplines and professions. 96.99\% participants were aware of the term 'Yagya' or 'Hawan' and indicated it as important for health, environment, and spiritual development and for attaining peace of mind too, while $86.21 \%$ believed to have Yagya as part of daily life. The study has shown that youth were aware with the general and basic understanding of Yagya used in ceremonial purposes and surprisingly they (58.83\%) also felt that it does not belong to one specific community or religion. However, there is also a category of youth (35.86\%) that did not agree nor did that know about it (5.3\%). It is also important to note that the questionnaire was circulated through social-media platforms and sharing of link was of personal interest, the majority of participants were familiar with Yagya, hence, such cross sectional study with wider population would justify the present research attempt.
\end{abstract}

Keywords. Yagya, Indian Youth, Perception, Indian culture

\section{Introduction}

Understanding Indian cultural and ritual perspective of India has been important aspect of the sociologists and culturists. Since the exposure of the Indian culture after industrial revolutions in past few centuries, perception of Indians towards their own rituals and cultural customs has changed from generations to generation. Along with these factors affecting the perception of Indian culture, the advancement of the science as well as socialnetworking has made the world a global village and influence customs, rituals and cultural practices (1).

Perspective on Indian culture can be availed through understanding of Yagya. Yagya is the backbone of the all the cultural traditions in India. 
There are vast dimensions of Yagya including its philosophy, message, importance, benefits and practice.

Scriptures depict Yagya as the central point and core tenet of the Indian culture (Rigveda 1/164/36 (2) and Atharveda 9/10/14 (3). It implies that in Indian culture, Yagya is said to be very important in the creation and operation of the universe.

In fact, for Indian culture since its existence, Yagya is a very pious and divine fire ritual. For the Agni (fire), Pandit Shriram Sharma Acharya has said in the book Yagya ek samagra upchar prakriya that Agni (fire) in Yagya is about discernment, consciousness and perception not merely about light, heat, color and energy (4). The first Mantra of Rigveda (the oldest Veda) depicts Agni as divine which signifies purity (Rigveda 1/1, (2)). Thus, the philosophy of the divine fire of the ritual Yagya represents that it guides life from darkness to light. This tradition, which has been performed since the Indian culture inception, aims to keep divinity of human alive.

In addition, to the fire ritual philosophy and purpose, there are multifaceted benefits of Yagya for performer. In all parts of India, all the rituals and customs are related to procedure of Yagya which is also known as hawan in which after the mantra chanting in front of the fire, the place resonates with the offering word 'Svaha' and offerings with medicinal herbs. The whole ritual ambience aims to provide, physical, mental and environmental and spiritual benefits to the participants. This tradition of fire ritual has given an immense wisdom, scientific approach and cultural bonding to Indian culture (5-8).

Various studies have tried to understand belief, faith, and perspective of Indians towards their own rituals, customs and culture. For example, Indian residing in India, in a survey by Nielsen Corporation (formerly known as AC Nielsen, 45\% of Indians have chosen the culture of their as best thing of living in India as per the report published in Times of Indian on 14 August 2007 (9). Additionally, a study published by Dharani Bala (2021) indicated that urban and rural population preferred their traditional local health practices when common outbreaks happens indicating prevalence of cultural traditions (10).

Besides, for Indians living outside, some studies indicated their perspectives towards their culture. A study on Indian Americans by Carnegie Endowment for International Peace concluded that for Indian Americans (around 75\%) religion plays a central role in their lives. $40 \%$ prays at least once a day and $27 \%$ attends weekly Hindu religious services in their locality (11). However, in contrast to aforesaid surveys, the work of Wiber J Scott's specifically on Indian youths studying in America had indicated that the students had gone to a level of 'difficult situation' towards understanding their culture and spirituality as it is (12).

With the aforesaid background i.e. dynamically changing global social and cultural environment, there is need to understand if the phenomenon exists the same or different for Indian youth in the present time. Thus, the present study aimed to understand the perspective of Indian Youth towards their culture and spirituality.

\section{Methodology}

The aim of the present research was to find general understanding of Indian Youths towards Yagya. To conduct the research, an online survey using a selfdesigned questionnaire with 11 questions was designed. Total 566 respondents of age 18 to 40 filled the form. The questionnaire was circulated through the social-media platforms and data collected from May to August 2021. The average 
age of the participants was 29 year (mean $+\mathrm{SD}=$ $28.98+6.32$ years) (Figure 1, top). Among total 566 participants, the maximum number of participants' profession was Job i.e. $39.58 \%(\mathrm{n}=224)$, while $18.55 \%(\mathrm{n}=105)$ had Business, while $31.98 \%$ $(n=181)$ were students and $9.89 \%(n=56)$ were unemployed (Figure 1, bottom).
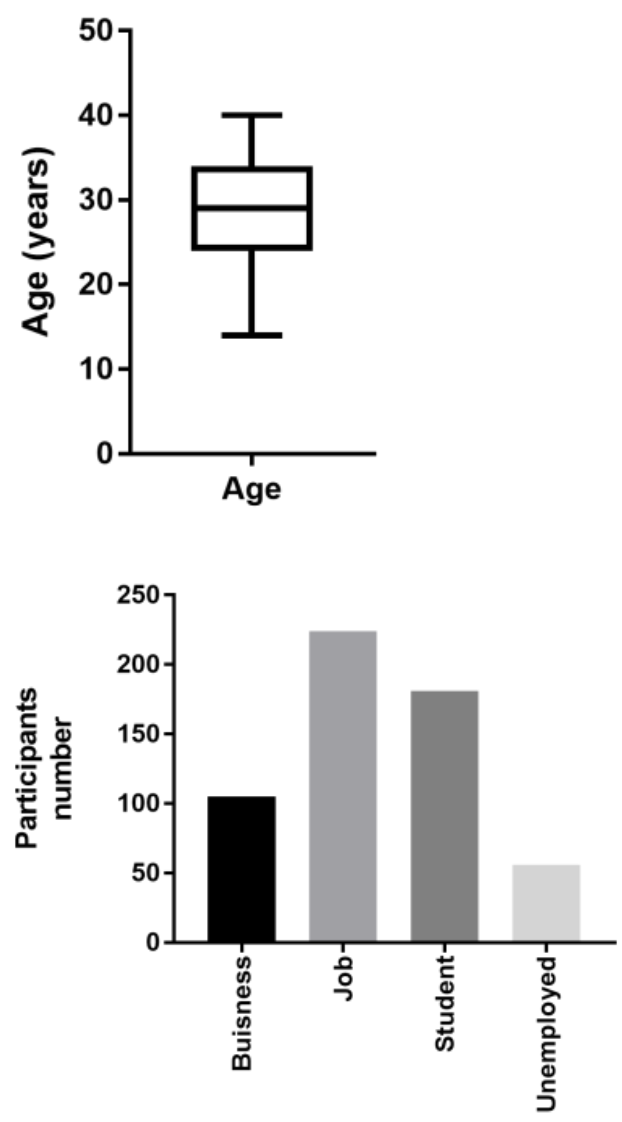

Figure 1. Demographics of the participants, age (top), and profession of the participants (bottom).

\section{Results}

Awareness and Implementation of Yagya in life of Youth

The study asked four questions to understand perspective of youth on awareness of Yagya and its need of implementation in the society and daily life. These questions were straight forward and their responses are defined in the figure $2 \mathrm{~A}-\mathrm{C}$.

In response to question "Are you familiar with the term 'Yagya' or 'Hawan'?" the figure 1A indicated that the majority i.e. $96.9 \%$ of the respondents were familiar with the term Yagya or hawan, while only $3.0 \%$ were unfamiliar with the term indicating they had neither witnessed the Yagya in their surroundings nor had heard about this (Figure 1A). Further asking to know experience of participants as participation in the Yagya, the second question was asked "Do you perform Yagya?"; where 85.33 of the respondents had chosen performed or attended Yagya at least once in their lifetimes, whereas $14.66 \%$ of the respondents had not performed Yagya even once (Figure 1A).

Continuing to understand the experience of the respondent, the study further asked their skill of performance i.e. "Do you know how to perform Yagya yourself?", in which $70.14 \%$ of the respondents knew how to perform Yagya themselves whereas $29.85 \%$ did not know how to perform (Figure 1A).

Further exploring to understand the regularity and practice of the Yagya in their life, as questions was asked i.e. "How often do you perform Yagya?". The respondents indicated that 50\% performed Yagya on specific occasions, while $11.13 \%$ performed once a month, 31.09\% performed once a week, while $7.77 \%$ of them never perform a Yagya (Figure 1B) indicating the intensity of the involvement of Yagya in the life. 
A

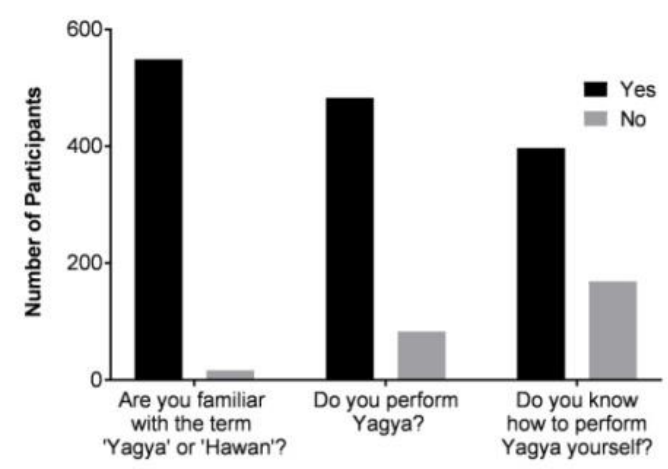

B

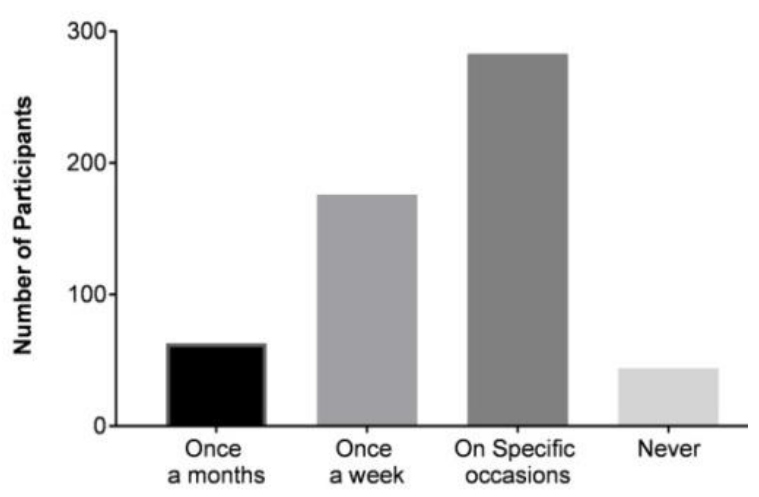

C How often do you perform Yagya?

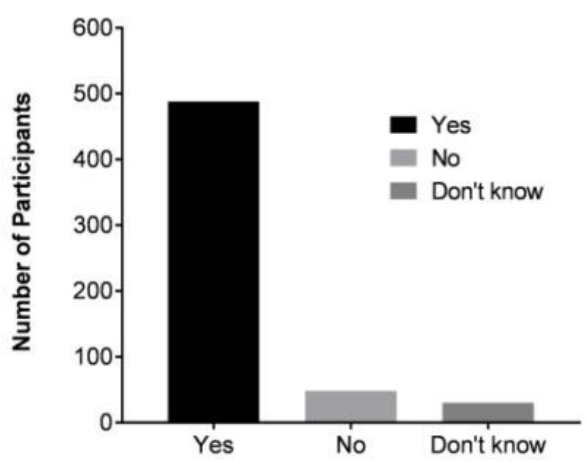

Should 'Yagya' be the part of daily lifestyle?

Figure 2.Awareness of Youth of Yagya $A$, and opinion for Implementation of Yagya in daily life,B.

The study further asked to understand their view on importance of Yagya as incorporation in the daily lifestyle, $86.21 \%$ of the respondents agreed that Yagya should be a part of the daily lifestyle whereas $8.48 \%$ of them did not agree with it while $5.3 \%$ did not know what to answer (Figure 1C). Perspective on Yagya as scientific, spiritual or religious process
The study also explored the consideration of Youth on nature of Yagya process if it is religious or scientific and/or spiritual process. $35.86 \%$ of the respondents had conception that Yagya belongs to a particular religion whereas $58.83 \%$ of them believed that Yagya did not belongs to a specific religion while $5.3 \%$ did not know the answer (Figure 3A). Further asking details on it indicated that $18.19 \%$ of the respondents considered Yagya to be a scientific and a spiritual process, $31.97 \%$ considered Yagya to be an only spiritual process, $42.9 \%$ believed it to be a scientific technique while $3.88 \%$ of could not be sure (Figure 3). It indicated though $35.86 \%$ believed it as religious activity (Figure 3A), only $3.00 \%$ believed that it be a strictly associated with religion only rather they indicated it agreed to have Yagya having a spiritual and/scientific component (Figure 3B).

A



B


Figure 3. Perspective of Youth of Yagya as a specific religion $A$, or as scientific and/or spiritual or religious process, B. 
Benefits and Utility of Yagya in the perspective of Youth

After evaluating the awareness of youth towards Yagya and their understanding of its nature, the study further evaluated their consideration of Yagya's utility in terms of physical, mental, environmental and spiritual benefits (Figure 4). $89.75 \%$ of the respondents believed that Yagya provided some physical health benefits, whereas $6.36 \%$ of them did not agree while $3.88 \%$ did not know the answer. Similarly, $94.69 \%$ of the respondents believed that Yagya had some mental health benefits, while $2.47 \%$ of them did not agree with the same and $2.82 \%$ did not know the answer. For the environmental benefits of Yagya, 92.22\% of the respondents' participants believed Yagya contributed in providing some benefits to the environment whereas $4.24 \%$ of them believed that it did not aid any kind benefits to the environment while $3.53 \%$ did not know the answer. In addition, for any kind of spiritual upliftment, $89.39 \%$ of the respondents believed Yagya providing benefit, whereas $3.88 \%$ did not think likewise and $6.71 \%$ didn't know the answer (Figure 4).

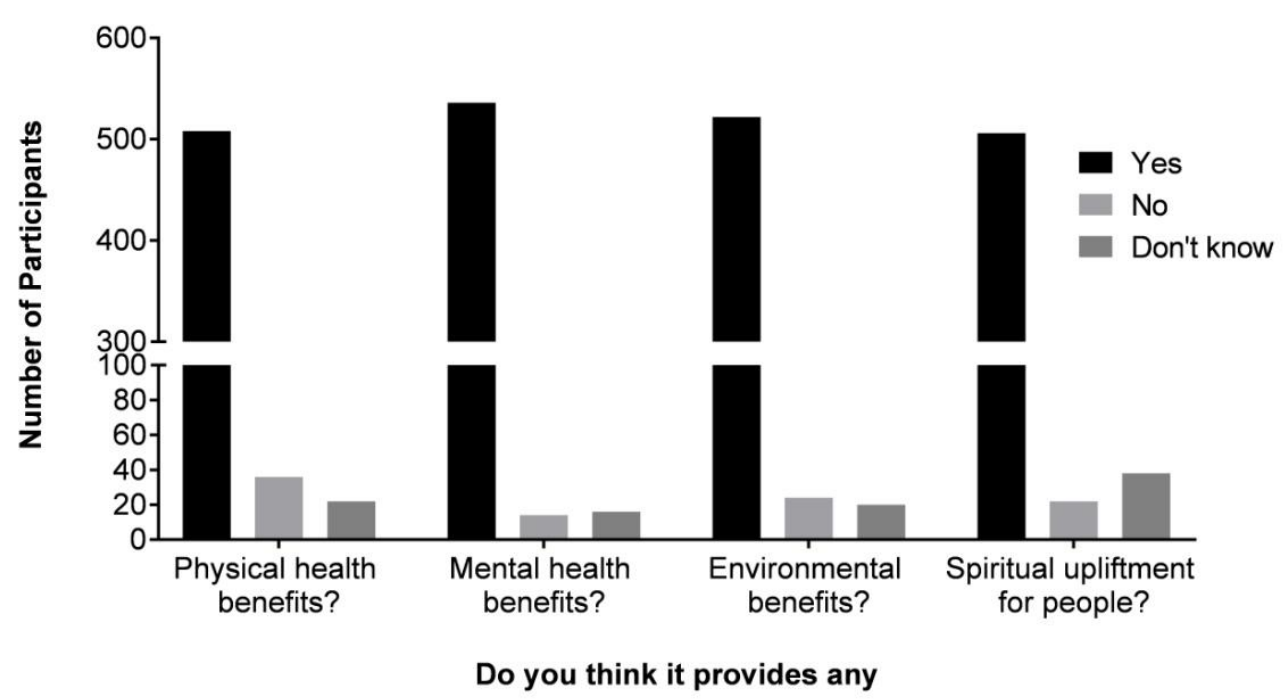

Figure 3.Perspective of Indian Youth of Yagyafor physical, mental, environmental benefit and spiritual upliftment

\section{Discussion\& Conclusion}

This study is an attempt to evaluate perspective of Indian youth towards the ancient Indian ritual Yagya. The study showed that the youth are more aware and inclined towards the ancient rituals and their benefits. Hence, it presents a great opportunity for social organization to reach them for such social welfare.

The present survey research shows a potential roadmap for spiritual and socio-scientific organizations to develop awareness for targeted youth to join such cultural movements and to impact daily life style for health and social benefits. Also the study indicated there is a need of inclusion of Yagya and such spiritual teaching to be part of curriculum in schools.

The study also presented a limit that the sharing of the Google form link through social media is choice based which might had affected the outcome. Hence this study can be further tested through huge mass population with more specific questions.

Yagya is the great heritage of Indian culture and the study presented a great inclination of youth toward 
their age old heritage and indicating a systematic approach from academic and research institutes, and governmental and social organizations.

\section{Conflict of interest}

The authors declare that they have no conflict of interest.

\section{Reference}

1. Pandya P (Ed.). Ek sahatrabdi ka safar (Journey of 1000 Centuries). Akhand Jyoti Magazine. February 2000, Page 06. http://literature.awgp.org/akhandjyoti/

2. Vedamurti Taponishtha Pt. Shriram Sharma Acharya and Bhagwatidevi Sharma (Editor). Rigveda Samhita (Revised Edition). Yug Nirman Yojana Extension Trust, Gayatri Tapobhoomi, Mathura-281003. 2013. Part 1

3. Vedamurti Taponishtha Pt. Shriram Sharma Acharya and Bhagwatidevi Sharma (Editor). Atharvaved Samhita (Revised Edition). Yug Nirman Yojana Extension Trust, Gayatri Tapobhoomi, Mathura-281003. 2013. Part 1-2

4. Brahmavarchas, editor. Yagya - Ek Samagra Upachar Prakriya (Hindi) (Yagya - A Holistic Therapy) Pandit Shriram Sharma Acharya Samagra Vangamaya - Volume 26. Revised edition. Mathura, Uttar Pradesh, India: Akhand Jyoti Sansthan; 2012

5. Saraswat A, Yadav G, Sharma U, Bisen K, Desai T, Bhagat S, Shrivastava V. Yagya Therapy as adjunct care tended to normalized level of thyroid hormones in 18 thyroid patients after 40 days of treatment. Interdis. J of Yagya Res. (Internet). 2021;3(2):19-8.https://doi.org/10.36018/ijyr.v3i2.61

6. Kumar V, Patidar H, Varma R. Galvanic Skin Response (GSR) signals reduced from Gayatri Mantra fire oblations during Yagya. Interdis. $\mathbf{J}$ of Yagya Res. (Internet). 2019;2(1):01-1.https://doi.org/10.36018/ijyr.v2i1.31

7. Singh R, Singh SK. Gayatri Mantra Chanting Helps Generate Higher Antimicrobial Activity of Yagya's Smoke. Interdis. J of Yagya Res. (Internet). 2018Apr.18 (cited 2021;1(1):09-14. https://doi.org/10.36018/ijyr.v1i1.6

8. Singh I, Rathor S. यज्ञ : भारतीय संस्कृति के मनोवैज्ञानिक मूल्यों का सार्वभौमिक संवाहक (Yagya: Universal conductor of psychological values of Indian culture). Interdis. J of Yagya Res. (Internet). 2018;1(1):2125.https://doi.org/10.36018/ijyr.v1i1.8

9. The Times of India. Indians most proud of their culture: Survey. Aug 14, 2007, 00:10 IST. Available from: http://timesofindia.indiatimes.com/articleshow/2278942.cms? utm_source=contentofinterest\&utm_medium=text\&utm_cam paign=cppst

10. Bala D. Attitudes, beliefs, and self-use of Kabasura Kudineer among urban and rural population in Tamil Nadu, India: A comparative cross-sectional study. J Family Med Prim Care. 2021;10(1):158

166.https://doi.org/10.4103/jfmpc.jfmpc_1634_20

11. Badrinathan S, Kapur D, Kay J, and Vaishnav M. Social Realities of Indian Americans: Results From the 2020 Indian American Attitudes Survey. Carnegie Endowment for International Peace, Publications Department, Washington, DC. 2021.

12. SCOTT WJ. Attachment to Indian Culture and the "Difficult Situation." Youth \& Society (Internet). 1986 Jun;17(4):381-95. Available from: https://doi.org/10.1177/0044118X86017004004 